\title{
Influence of Alloy Microstructure on the Microshear Bond Strength of Basic Alloys to a Resin Luting Cement
}

\author{
José BAUER ${ }^{1}$ \\ José Ferreira COSTA ${ }^{1}$ \\ Ceci Nunes CARVALHO ${ }^{2}$ \\ Douglas Nesadal de SOUZA ${ }^{3}$ \\ Alessandro Dourado LOGUERCIO ${ }^{4}$ \\ Rosa Helena Miranda GRANDE ${ }^{5}$
${ }^{1}$ Department of Dentistry I, Dental School, UFMA - Federal University of Maranhão, São Luis, MA, Brazil ${ }^{2}$ Department of Endodontics, Dental School, USP - University of São Paulo, São Paulo, SP, Brazil ${ }^{3}$ Oral Biology Research Center, Department of Dental Materials, Dental School, USP - University of São Paulo, São Paulo, SP, Brazil ${ }^{4}$ Department of Restorative Dentistry, UEPG - State University of Ponta Grossa, Ponta Grossa, PR, Brazil \\ ${ }_{5}^{5}$ Department of Dental Materials, Dental School, USP - University of São Paulo São Paulo, SP, Brazil
}

\begin{abstract}
The aim of this study was to evaluate the influence of microstructure and composition of basic alloys on their microshear bond strength ( $\mu$ SBS) to resin luting cement. The alloys used were: Supreme Cast-V (SC), Tilite Star (TS), Wiron 99 (W9), VeraBond II (VBII), VeraBond (VB), Remanium (RM) and IPS d.SIGN 30 (IPS). Five wax patterns (13mm in diameter and 4mm height) were invested, and cast in a centrifugal casting machine for each basic alloy. The specimens were embedded in resin, polished with a $\mathrm{SiC}$ paper and sandblasted. After cleaning the metal surfaces, six tygon tubes $(0.5 \mathrm{~mm}$ height and $0.75 \mathrm{~mm}$ in diameter $)$ were placed on each alloy surface, the resin cement (Panavia F) was inserted, and the excess was removed before light-curing. After storage $\left(24 \mathrm{~h} / 37^{\circ} \mathrm{C}\right)$, the specimens were subjected to $\mu$ SBS testing $(0.5 \mathrm{~mm} / \mathrm{min})$. The data were subjected to a one-way repeated measures analysis of variance and Turkey's test $(\alpha=0.05)$. After polishing, their microstructures were revealed with specific conditioners. The highest $\mu$ SBS (mean/ standard deviation in $\mathrm{MPa}$ ) were observed in the alloys with dendritic structure, eutectic formation or precipitation: VB (30.6/1.7), TS (29.8/0.9), SC (30.6/1.7), with the exception of IPS (31.1/0.9) which showed high $\mu$ SBS but no eutectic formation. The W9 (28.1/1.5), VBII (25.9/2.0) and RM (25.9/0.9) showed the lowest $\mu$ SBS and no eutectic formation. It seems that alloys with eutectic formation provide the highest $\mu$ SBS values when bonded to a light-cured resin luting cement.
\end{abstract}

Key Words: dental cements, dental alloys, shear strength.

\section{INTRODUCTION}

For decades, metal-ceramic dental prostheses have been used in dentistry with good clinical performance, esthetics and durability. The aim of these restorations is to combine the fracture resistance of the metal substructure with the esthetic properties of porcelain. Noble alloys have always been the first choice for ceramometal prostheses, mainly those containing gold, palladium and platinum. However, several economic crises in the last century prevented the day-to-day use of these alloys. This led to the widespread use of basic alloys, such as nickel-chromium (Ni-Cr) and cobalt-chromium (Co-Cr), as frameworks for porcelain, due to their high mechanical strength, high modulus of elasticity and good adhesion to porcelain $(1,2)$.

The success of any indirect restorative procedure relies on bonding indirect restorations to tooth structures. The achievement of a strong and durable adhesive bond between a metal framework and a luting agent is

Correspondence: Prof. Dr. José Bauer, Departamento de Odontologia I, Curso de Odontologia, Universidade Federal do Maranhão, Campus Universitário do Bacanga, Avenida dos Portugueses, S/N, 65085-680 São Luis, MA, Brasil. Tel: +55-98-8892-7768. Fax: +55-98-3301-8570. e-mail: bauer@ufma.br 
important to withstand the many and varied changes in the oral environment (3). In general, metal restorations are cemented with zinc phosphate. However, the high solubility, lack of adhesion to tooth structure and particularly the high stiffness that prevents proper load transmission to the dental structure, have shifted the focus for evaluating resin luting cements. Resin luting cements are characterized by their high fracture strength, adequate bond to the dental structure and low solubility when exposed to oral fluids $(4,5)$.

Bond strength between resins and metals is a physicochemical phenomenon, resulting in mechanical interlocking of the cement with the metal surface and chemical interactions between the oxides present on the surface of metals and the carboxylic or phosphoric acid derivatives present in the cements $(6,7)$.

There are great variations in the composition of basic alloys within the same classification ( $\mathrm{Co}-\mathrm{Cr}$ and $\mathrm{Ni}-\mathrm{Cr}$ ), leading to the formation of different oxides on their surfaces (2), which might alter the bond quality in some aspects (8). It is known that alterations in the composition of an alloy lead to the formation of single microstructures (9) and the generated oxides are fundamental factors in determining resistance to corrosion, biocompatibility, and bonding both to polymer and ceramic materials. In spite of this, little is known about the relationship between the microstructure of basic alloys and the bond to resin cements.

The aim of this study was to evaluate the influence of microstructure of 7 basic alloys: two $\mathrm{Co}-\mathrm{Cr}$ and 5 $\mathrm{Ni}-\mathrm{Cr}$ ( 2 with and 3 without beryllium - Be) on the microshear bond strength ( $\mu$ SBS) to a resin luting cement.

\section{MATERIAL AND METHODS}

Seven basic alloys for ceramometal prostheses were used in this study. VeraBond (Aalba Dental Inc., Cordelia, CA, USA), Suprem Cast V (Talladium Inc., Valencia, CA, USA), Tilite Star (Talladium Inc.), Wiron 99 (Bego, Bremen, Germany) and VeraBond II (Aalba Dental Inc., Cordelia, CA, USA) are Ni-Cr alloys while IPS d. SIGN 30 (Ivoclar Vivadent, Schaan, Liechtenstein) and Remanium (Dentaurum, Pforzheim, Germany) are Co-Cr alloys. The compositions of these alloys are shown in Table 1.

\section{Casting}

Wax disks measuring $13 \mathrm{~mm}$ in diameter and $4 \mathrm{~mm}$ high $(n=5)$ were fabricated using a metal matrix, included in silicone rings with phosphate coating (Microfine 1600; Talladium Inc.) and cast in an electromagnetic induction machine (F. 1li Manfredi, San Secondo di Pinerolo, Torin, Italy). After unmolding, the disks were airborne particle abraded with aluminum oxide $(50 \mu \mathrm{m})$, embedded in bakelite resin and polished with silicon carbide abrasive papers of decreasing abrasiveness up

Table 1. Composition of alloys and resin cements used in this study.

\begin{tabular}{|c|c|c|c|c|c|c|c|c|c|}
\hline Alloy & $\mathrm{Ni}$ & $\mathrm{Co}$ & $\mathrm{Cr}$ & $\mathrm{Nb}$ & Mo & $\mathrm{Be}$ & $\mathrm{Si}$ & $\mathrm{Al}$ & $\mathrm{Ti}$ \\
\hline Verabond (Ni-Cr-Be) & 77.95 & 0.45 & 12.6 & & 5 & 1.95 & & 2.99 & 0.35 \\
\hline Suprem Cast V (Ni-Cr-Be) & 74.0 & - & 14.0 & - & 8.5 & 1.8 & - & 1.7 & - \\
\hline Tilite Star (Ni-Cr) & 76.5 & - & 13.5 & - & 6.0 & - & - & - & 4.0 \\
\hline Wiron 99 (Ni-Cr) & 65.0 & - & 22.5 & 1.0 & 9.5 & - & 1.0 & 2.2 & 0.4 \\
\hline VeraBond II (Ni-Cr) & 77.05 & & 12.5 & 4 & 4.25 & - & 0.5 & 2.25 & 0.45 \\
\hline d. Sign 30 (Co-Cr) & - & 60.2 & 30.1 & 3.2 & 1 & - & - & 1 & - \\
\hline Remanium (Co-Cr) & - & 65 & 28 & - & 4.5 & - & 1.6 & - & - \\
\hline $\begin{array}{l}\text { Resin Cement } \\
\text { (Panavia F 2.0) }\end{array}$ & \multicolumn{4}{|c|}{$\begin{array}{l}\text { MDP, hydrophobic aromatic } \\
\text { dimethacrylates, hydrophobic aliphatic } \\
\text { dimethacrylates, hydrophilic aliphatic } \\
\text { dimethacrylates, silanated silica filler, } \\
\text { silanated colloidal silica, } \\
\text { dl-camphoroquinone, initiators }\end{array}$} & \multicolumn{5}{|c|}{$\begin{array}{l}\text { Paste B: } \\
\text { Hydrophobic aromatic dimethacrylates, hydrophobic } \\
\text { aliphatic dimethacrylates, hydrophilic aliphatic } \\
\text { dimethacrylates, silanated barium glass filler, } \\
\text { initiators, accelerators, pigments }\end{array}$} \\
\hline
\end{tabular}


to 2000-grit (Norton, São Paulo, SP, Brazil).

Samples were prepared in a standardized manner using $110 \mu \mathrm{m}$ aluminum oxide for $30 \mathrm{~s}$ at a distance of $5 \mathrm{~mm}$ and pressure of $60 \mathrm{psi}$. After this, the samples were rinsed in an ultrasonic bath for $15 \mathrm{~s}$ to remove any excess particles. The surface was ultrasonically cleaned in isopropanol (96\%) for $3 \mathrm{~min}$ and air-dried for $3 \min (10)$.

Six tygon tubes (TYG-030; Small Parts Inc., Miami Lakes, FL, USA) $0.75 \mathrm{~mm}$ in diameter and 0.5 $\mathrm{mm}$ high were placed on each alloy surface and were filled with Panavia F (Kuraray Medical Inc., Tokyo, Japan) luting cement. The resin cement was applied and handled according to the manufacturers' instructions. All light-curing procedures were performed with a halogen lamp (Optilux 500; Demetron, Danbury, CT, USA) for $20 \mathrm{~s}$, with a standard irradiation mode of $600 \mathrm{~mW} / \mathrm{cm}^{2}$. The power density of the curing device was regularly checked with a curing radiometer (Demetron).

The specimens were stored in water at $37^{\circ} \mathrm{C}$ for $24 \mathrm{~h}$. The tygon tubes were removed with a blade and then checked under a light stereomicroscope $(\times 10)$ to discard any specimens with evident air bubbles or gaps at the interface. The resin cement flash extending beyond the alloy base was also removed with a blade.

A universal testing machine (model 5565; Instron, Canton, MA, USA) was used for the $\mu$ SBS test. The specimens were attached to the testing device which, in turn, was placed in the universal testing machine. A thin 0.2-mm-diameter wire (Morelli Ortodontia, São Paulo, SP, Brazil) was looped around the composite resin cylinder, around half its circumference, and gently held flush against the interface. A shear force was applied to each specimen at a crosshead speed of $0.5 \mathrm{~mm} / \mathrm{min}$ until failure. The force required to produce failure was then

Table 2. Solutions used to condition the alloys in this study.

\begin{tabular}{|c|c|c|}
\hline Alloy & Basic composition & Etching solutions \\
\hline VeraBond & $\mathrm{Ni}-\mathrm{Cr}-\mathrm{Be}$ & $\mathrm{C}_{2} \mathrm{H}_{4} \mathrm{O}_{2}+\mathrm{HNO}_{3}(1: 1)$ \\
\hline Suprem Cast V & $\mathrm{Ni}-\mathrm{Cr}-\mathrm{Be}$ & $\mathrm{C}_{2} \mathrm{H}_{4} \mathrm{O}_{2}+\mathrm{HNO}_{3}(1: 1)$ \\
\hline Tilite Star & $\mathrm{Ni}-\mathrm{Cr}$ & $\mathrm{C}_{2} \mathrm{H}_{4} \mathrm{O}_{2}+\mathrm{HNO}_{3}(1: 1)$ \\
\hline Wiron 99 & $\mathrm{Ni}-\mathrm{Cr}$ & $\begin{array}{l}20 \mathrm{~mL} \mathrm{HCl}+0.5 \mathrm{~mL} \\
\mathrm{HNO}_{3}+6.5 \mathrm{~g} \mathrm{FeCl}_{3}\end{array}$ \\
\hline VeraBond II & $\mathrm{Ni}-\mathrm{Cr}$ & $\mathrm{HNO}_{3}+\mathrm{HCl}(1: 3)$ \\
\hline d.Sign 30 & $\mathrm{Co}-\mathrm{Cr}$ & $\mathrm{HNO}_{3}+\mathrm{HCl}(1: 3)$ \\
\hline Remanium CD & $\mathrm{Co}-\mathrm{Cr}$ & $\mathrm{HCl}+\mathrm{H}_{2} \mathrm{O}_{2}(10: 1)$ \\
\hline
\end{tabular}

divided by the bonded area of the vinyl tube and the bond strength values were expressed in MPa.

The $\mu$ SBS values of all specimens from the same alloy were averaged for statistical purposes. The data were subjected to an one-way repeated measures analysis of variance and Tukey's test at a significance level of 5\%.

\section{Microstructure}

The alloy specimens were polished with silicon carbide papers of decreasing abrasiveness (\#180 to \#2000; Norton) and a $0.05 \mu \mathrm{m}$ silica colloidal solution (Struers, Rødovre, Denmark), and then etched using specific conditioners (Table 2). The prepared surfaces were examined only qualitatively using an optical stereomicroscope (HMV-2; Shimadzu, Tokyo, Japan).

\section{RESULTS}

The overall $\mu$ SBS values are shown in Table 3. Statistically significant differences were observed among the groups $(\mathrm{p}=0.0001)$. Verabond, Suprem Cast, Tilite Star (Ni-Cr alloys) and Co-d-SIGN 30 (Co-Cr alloy) showed the highest $\mu$ SBS values, which were significantly higher than those obtained with Wiron 99, Verabond II (Ni-Cr alloys) and Remanium CD (Co-Cr alloy).

All alloys exhibited a solid solution matrix in a typical dendritic arrangement, irrespective of their composition (Ni-Cr or Co-Cr). The alloy structures are shown in Figure 1.

Figures 1A, 1B and 1C (Suprem Cast V, Tilite Star and Verabond, respectively) are identical, showing

Table 3. Shear bond strength ( $\mu$ SBS) means and standard deviations (MPa).

\begin{tabular}{lcc}
\hline Alloy & Basic composition & $\mu$ SBS \\
\hline VeraBond & Ni-Cr-Be & $30.64(1.7)^{\mathrm{a}}$ \\
Suprem Cast V & Ni-Cr-Be & $28.83(2.3)^{\mathrm{a}, \mathrm{b}}$ \\
Tilite Star & Ni-Cr & $29.82(0.9)^{\mathrm{a}}$ \\
Wiron 99 & Ni-Cr & $28.10(1.5)^{\mathrm{b}, \mathrm{c}}$ \\
VeraBond II & Ni-Cr & $25.46(2.0)^{\mathrm{c}}$ \\
d.Sign 30 & Co-Cr & $31.11(0.9)^{\mathrm{a}}$ \\
Remanium CD & Co-Cr & $25.96(0.9)^{\mathrm{c}}$ \\
\hline
\end{tabular}

Same letters indicate no statistically significant difference among alloys $(\mathrm{p}<0.05)$. 
a dentritic structure with dendrites (white arrows) and interdendritic regions (black arrows). A "light" (white arrows) phase with an fcc structure and was etched with difficulty, has a nobler phase. On the contrary, a "dark" (black arrows) phase that was etched more easily, has a less noble phase with an hcp structure.

Figures $1 \mathrm{D}, 1 \mathrm{E}, 1 \mathrm{~F}$ and $1 \mathrm{G}$ are representative images of Wiron 99, VeraBond 2, Remanium CD and d.Sign 30 , respectively. These alloys are characterized by a large volume of solid solution or dendrites and a small or nonexistent interdendritic portion and precipitates.

It is worth mentioning that Figures $1 \mathrm{E}$ and $1 \mathrm{~F}$ (Wiron 99 and d.Sign 30) showed a large volume of dendritic portion (white arrows) and only a few precipitates within them and at the intergranular limits (gray arrows). Figure 1F (Verabond 2) as cast, shows a large dendritic structure (white arrows) and the presence of precipitates is not visible at the intergranular limit (black arrows).

\section{DISCUSSION}

Although there is a tendency to use esthetic restorative and prosthetic materials such as direct or indirect resin composite inlays, adhesive metal-free bonded bridges (partial dentures), and all-ceramic restorations, dental casting alloys are still used in a variety of dental applications. The basic alloys are of interest for conducting studies due to their low cost. However, the interaction of these alloys with luting agents is still not clear, particularly those known as resinous products.

There are innumerable factors that will influence the bond strength of a resin cement to a metal alloy, among which the following are outstanding: alloy $(8,11)$ and cement (12) compositions, treatments to which the part is subjected, use of agents to improve bond durability (5) and cleaning of the part $(10,13)$.

With regard to the composition of Ni-Cr alloys, there are still scarce published data $(11,13)$. However, there are two clear reasons for the high bond strength values of these alloys: the presence of $\mathrm{Be}(14)$ and the high chromium content in the Ni-Cr-based alloys (8).

$\mathrm{Be}$ is added to reduce the melting point of alloys and thus improve castability, due to the formation of the eutectic $\mathrm{Ni}-\mathrm{Be}$ phases at low melting temperature (15). Another feature associated with $\mathrm{Be}$ is the formation of oxide films in the inner parts of the interdendritic eutectic $\mathrm{Ni}-\mathrm{Be}$ phases or on the dendrites, which provides a strong oxide that results in excellent bonding (12). The
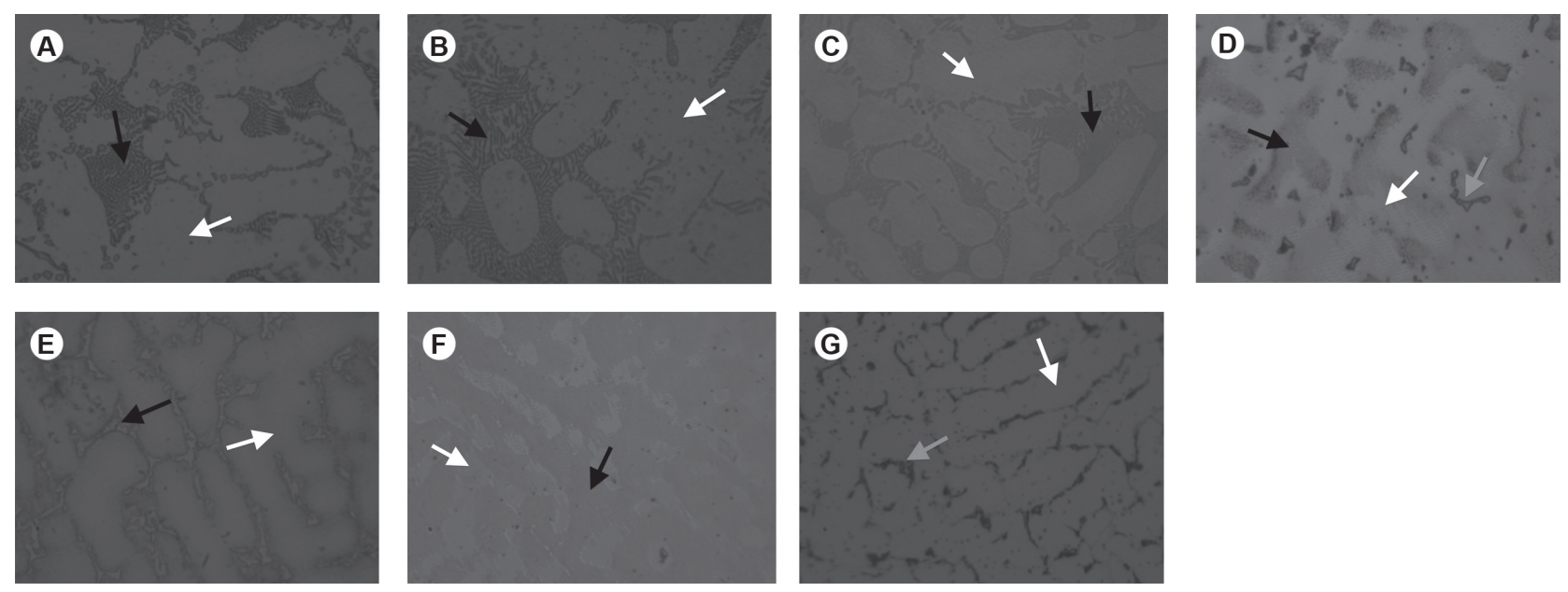

Figure 1. Optical micrographs showing the structure of the alloys: A: Supreme Cast V alloy (Ni-Cr-Be) - Dendrites (white arrows) and interdendritic region (black arrows) probably eutectic Ni-Be. B: Tilite Star alloy (Ni-Cr) - Dendrites (white arrows) and interdendritic region (black arrows). C: VeraBond alloy (Ni-Cr-Be) - Dendrites (white arrows) and interdendritic region (black arrows) probably eutectic Ni-Be. D: Wiron 99 alloy (Ni-Cr) - Large volume of dendritic portion (white arrows) and only some precipitation (gray arrows) inside and on the intergranular limits (black arrows). E: VeraBond II alloy (Ni-Cr) - Large volume of dendritic portion (white arrows) and on the intergranular limits (black arrows). It is not possible to verify the presence of precipitates. F: Remanium alloy (Co-Cr) Alloy is characterized by the large volume of solid or dendritic solutions (white arrows) and interdendritic portion (black arrows), an alloy that is difficult to characterize due to the Cr high content and areas of high surface energy. G: d.Sign 30 alloy (Co-Cr) - Alloy is characterized by the large volume of solid or dendritic solution (white arrows) and a large volume of precipitates located at the intergranular limits (gray arrows). 
interdendritic eutectic $\mathrm{Ni}-\mathrm{Be}$ is the component with the highest free energy (16), which favors the bond to other materials (ceramic or resin). This becomes evident when the bond strength values of the alloys containing Be are observed (Suprem Cast V and VeraBond), confirming the microstructure analysis of the alloys. It is possible to observe the typical lamellar formation of eutectic $\mathrm{Ni}-\mathrm{Be}$ on the interdendritic portion of these alloys, confirming the findings in the literature (9).

Another alloy that showed good results was Tilite Star. Although the manufacturer of this alloy claimed that there is no Be in its composition, the microstructure analysis of Tilite Star shows evidence of lamellar eutectics in its interdendritic portion, very similar to those in the Supreme Cast V and VeraBond alloys. This is an indication that the Tilite Star alloy does perhaps have $\mathrm{Be}$ in its composition, which would help explaining its high bond strength values.

In spite of the excellent results of $\mathrm{Ni}-\mathrm{Cr}$ alloys containing Be in bond strength tests with ceramic and metal materials, this alloy causes some mistrust in the scientific community because of biological problems related to the element $\mathrm{Be}$. Despite its usefulness, a number of standard setting agencies have determined that $\mathrm{Be}$ is a carcinogen (17). Therefore, in the opinion of some researchers, these alloys should not be used clinically $(18,19)$. Some Be-free Ni-Cr alloys present a high $\mathrm{Cr}$ content. Similarly, chromium leads to the formation of an oxide layer that facilitates the chemical interaction of the cement with the alloy, which has been demonstrated in previous studies $(8,20)$. This was indeed confirmed in the present study. The Wiron 99 alloy, which contains approximately $22.9 \% \mathrm{Cr}$, showed higher bond strength value when compared with VeraBond II alloy that contains only $12.5 \% \mathrm{Cr}$.

Panavia F 2.0 resin cement contains MDP monomer (10-Methacryloyloxydecyl dihydrogen phosphate), which can react chemically with the chromium oxide layer created on the cast metal surfaces $(21,22)$ by means of covalent bonds $(13)$. In the present study, the alloy primer was not used, in spite of being indicated by the manufacturer for application on the metal surface before cementation of the resin material. Various studies have demonstrated that basic alloys oxidize more easily and do not need a primer, and that the use of metal primers on basic alloys may reduce the bond strength values $(3,5)$.

For the Co-Cr alloys assessed in this study, the $\mathrm{Cr}$ content does not seem to be related to bond strength. In spite of the very close percentages of $\mathrm{Cr}$ concentrations in the d.Sign 30 (30.1\%) and Remanium CD (28\%) alloys, these materials showed discrepant results of bond strength to resin cement. In the Remanium CD alloy, it was not possible to distinguish an interdendritic portion and the formation of intermetallic composites and precipitates, leaving the impression that this is an alloy with a solid single phase structure with possibly complete miscibility of the components. Whereas the microstructure of d.Sign 30 alloy shows the formation of an intermetallic composite probably rich in $\mathrm{Nb}$ (23) or a Co-Al precipitate (Fig. 1G - gray arrows). This may explain the great difference between the values of these two Co-Cr alloys, because of the formation of an interdendritic portion seems to favor the attainment of higher bond strength values, since there is greater surface energy in this region (16).

When this is compared with the results of the $\mathrm{Ni}$ $\mathrm{Cr}$ alloys containing $\mathrm{Be}$ and one of the $\mathrm{Co}-\mathrm{Cr}$ alloys, the values are very close. However, the use of alloys that contain $\mathrm{Ni}$ in their composition is constantly questioned due to their allergenic potential. Therefore, Co-Cr alloys are an excellent alternative to the problematic $\mathrm{Ni}-\mathrm{Cr}$ alloys.

The presence of eutectic formation or the presence of precipitates in the microstructure of $\mathrm{Ni}-\mathrm{Cr}$ and $\mathrm{Co}-$ $\mathrm{Cr}$ alloys appears to contribute to the bond to resin cements. Clinically, one may predict that using these alloys with eutectic formation, there is a lower risk of loss of restoration with metallic frameworks.

The presence of innumerable constituents in the composition of Ni-Cr (24) and Co-Cr (25) alloys makes it difficult to identify the precipitates forming after casting. In various figures of the present study, it is possible to observe the presence of precipitates. However, due to their very small size, it is unfeasible to identify them and thereby support their relationship with bonding. Another factor that may influence the results is the airborne particle abrasion used before the resin cement. Due to the different microhardness values of the alloys, the resultant roughness of this airborne particle abrasion may be different for each type of alloy. However, several studies have shown that some of these alloys have very close microhardness values $(9,24,25)$ and in the present study, different bond strength values were found with the same resin cement.

The presence of eutectic formation or the presence of precipitates in the microstructure of $\mathrm{Ni}-\mathrm{Cr}$ and $\mathrm{Co}-\mathrm{Cr}$ alloys appears to contribute to the bond to resin cements. 


\section{RESUMO}

O objetivo deste estudo foi avaliar a influência da microestrutura e da composição de ligas básicas quanto à resistência de união (RU) a um agente cimentante resinoso. Foram usadas as seguintes ligas: Supreme Cast-V (SC), Tilite Star (TS), Wiron 99 (W9), VeraBond II (VBII), VeraBond (VB), Remanium (RM) and IPS d.SIGN 30 (IPS). Cinco padrões em cera (13 mm de diâmetro e 4 $\mathrm{mm}$ de altura) para cada uma das ligas básicas foram incluídos e fundidos em uma máquina de fundição. As amostras foram então embutidas em resina, polidas com lixas e jateadas. Após a limpeza das superfícies, seis cilindros de tygon tube $(0,5 \mathrm{~mm}$ de altura e $0,75 \mathrm{~mm}$ de diâmetro) foram colocados sobre a superficie da liga e preenchida com cimento resinoso (Panavia F), o excesso foi removido antes da fotoativação. Após armazenagem $\left(24 \mathrm{~h} / 37^{\circ} \mathrm{C}\right)$, cada amostra foi ensaiada por microcisalhamento a $0,5 \mathrm{~mm} / \mathrm{min}$. Os dados foram tratados por análise de variância para e medidas repetidas e teste Tukey $(\alpha=0,05)$. Para avaliar a microesturutura, as mesmas amostras foram polidas e condicionadas com solução específica. Os valores mais altos da RU (média/desvio padrão em $\mathrm{MPa}$ ) foram encontrados para as ligas com estrutura dendrítica, formação eutética e precipitados: VB $(30,6 / 1,7)$, TS $(29,8 / 0,9)$, SC $(30,6 / 1,7)$, com exceção da IPS $(31,1 / 0,9)$ que apresentou alto valor de RU, mas sem formação eutética. As ligas W9 $(28,1 / 1,5)$, VBII $(25,9 / 2,0)$ and RM $(25,9 / 0,9)$ apresentaram os menores valores de RU e ausência de formação eutética. Pode-se inferir que os valores mais elevados de resistência de união ao cimento resinoso fotoativado ocorre com as ligas que apresentam formação de eutético.

\section{ACKNOWLEDGEMENTS}

This study was partialled supported by CNPq (479369/2009-7; 310874/09-2) and FAPEMA (00486/10,01164/09 and 016/2011) grants.

\section{REFERENCES}

1. Galo R, Ribeiro RF, Rodrigues RC, Rocha LA, de Mattos MGC. Effects of chemical composition on the corrosion of dental alloys. Braz Dent J 2012;23:141-148.

2. Huang HH, Lin MC, Lee TH, Yang HW, Chen FL, Wu SC, et al.. Effect of chemical composition of Ni-Cr dental casting alloys on the bonding characterization between porcelain and metal. J Oral Rehabil 2005;32:206-212.

3. Fonseca RG, de Almeida JG, Haneda IG, Adabo GL. Effect of metal primers on bond strength of resin cements to base metals. J Prosthet Dent 2009;101:262-268.

4. Hill E. Dental cements for definitive luting: a review and practical clinical considerations. Dent Clin N Am 2007;51:643-658.

5. Di Francescantonio M, de Oliveira MT, Garcia RN, Romanini JC, da Silva NR, Giannini M. Bond strength of resin cements to Co$\mathrm{Cr}$ and $\mathrm{Ni}-\mathrm{Cr}$ metal alloys using adhesive primers. J Prosthodont 2010;19:125-129.

6. Yoshida K, Matsumura H, Atsuta M. Monomer composition and bond strength of light-cured 4-META opaque resin. J Dent Res 1990;69:849-851.
7. Yoshida K, Taira Y, Matsumura H, Atsuta M. Effect of adhesive metal primers on bonding a prosthetic composite resin to metals. J Prosthet Dent 1993;69:357-362.

8. Salonga JP, Matsumura H, Yasuda K, Yamabe Y. Bond strength of adhesive resin to three nickel-chromium alloys with varying chromium content. J Prosthet Dent 1994;72:582-584.

9. Bauer JR, Loguercio AD, Reis A, Rodrigues Filho LE. Microhardness of Ni-Cr alloys under different casting conditions. Braz Oral Res 2006;20:40-46.

10. Quaas AC, Heide S, Freitag S, Kern M. Influence of metal cleaning methods on the resin bond strength to Ni-Cr alloy. Dent Mater 2005;21:192-200.

11. Rubo JH, Pegoraro LF, Ferreira PM. A comparison of tensile bond strengths of resin-retained prostheses made using five alloys. J Prosthet Dent 1996;9:277-281.

12. Mackert JR, Parry EE, Fairhurst CW. Oxide morphology and adherence on dental alloys designed for porcelain bonding. Oxid Met 1986;5:319-333.

13. Rubo JH, Pegoraro LF. Tensile bond strength of a composite resin cement for bonded prosthesis to various dental alloys. J Prosthet Dent 1995; 74:230-234.

14. Lin TH, Chang HJ, Chung KH. Interfacial strengths of various alloy surface treatments for resin-bonded fixed partial dentures. J Prosthet Dent 1990;64:158-162.

15. Bezzon OL, de Mattos MGC, Ribeiro RF, Rollo JM. Effect of beryllium on the castability and resistance of cerometal bonds in nickel-chromium alloys. J Prosthet Dent 1998;80:570-574.

16. Baran GR. The metallurgy of Ni-Cr alloys for fixed prosthodontics. J Prosthet Dent 1983;50:639-650.

17. Gordon T, Bowser D. Beryllium: genotoxicity and carcinogenicity. Mutat Res 2003;533:99-105.

18. Geis-Gerstorfer J, Pässler K. Studies on the influence of Be content on the corrosion behavior and mechanical properties of $\mathrm{Ni}-25 \mathrm{Cr}$ 10Mo alloys. Dent Mater 1993;9:177-181.

19. Pagnano VO, Esquivel Mde C, Leal MB, Felipucci DN, Bezzon OL. Effect of casting atmosphere on the shear bond strength of a ceramic to Ni-Cr and Ni-Cr-Be alloys. Braz Dent J 2009;20:138142.

20. Tanaka T, Fujiyama E, Shimizu H, Takaki A, Atsuta M. Surface treatment of nonprecious alloys for adhesion-fixed partial dentures. J Prosthet Dent 1986;55:456-462.

21. Yoshida K, Atsuta M. Effect of adhesive primers for noble metals on shear bond strengths of resin cements. J Dent 1997;25:53-58.

22. Watanabe F, Powers JM, Lorey RE. In vitro bonding of prosthodontic adhesives to dental alloys. J Dent Res 1988;67:479483.

23. Reclaru L, Lüthy H, Eschler PY, Blatter A, Susz C. Corrosion behaviour of cobalt-chromium dental alloys doped with precious metals. Biomaterials 2005;26:4358-4365.

24. Bauer J, Costa JF, Carvalho CN, Grande RH, Loguercio AD, Reis A. Characterization of two Ni-Cr dental alloys and the influence of casting mode on mechanical properties. J Prosthodont Res 2012;56:264-271.

25. Bauer JR, Grande RH, Rodrigues-Filho LE, Pinto MM, Loguercio AD. Does the casting mode influence microstructure, fracture and properties of different metal ceramic alloys? Braz Oral Res 2012;26:190-196.

Received November 16, 2011

Accepted September 11, 2012 